DOI: https://doi.org/10.24867/10FA05Omoran

\title{
ПРОЈЕКАТ ИНТЕГРИСАЊА ПРИРОДЕ У ПОСЛОВНИ ПРОСТОР ЗГРАДЕ У НОВОМ САДУ ПРИМЕНОМ БИОМИМИКРИЈЕ
}

\section{PROJECT OF INTEGRATING NATURE INTO THE BUSINESS SPACE OF A BUILDING IN NOVI SAD BY APPLYING BIOMIMICRY}

\section{Кристина Оморан, Факултет техничких наука, Нови Сад}

\section{Област - АРХИТЕКТУРА}

Кратак садржај - Овај рад истражује појам биомимикрије, анализирајући юене принципе и могућности њене примене, како у архитектури уопштено тако и у самом ентеријеру. Извршена је анализа ьеног развоја кроз историју као и развој биомиметичких материјала. Осим „добрих“ примера примене биомимикрије, приказани су и они који се грешком сматрају биомимикријом, уз јасно објашьење зашто то нису. На крају, неки од изучених принципа примењени су у ентеријеру и екстеријеру зграде „Elektrolux“ која се налази у Новом Садy.

Кључне речи: Биомимикрија, биомиметика, биомиметички материјали, пословне зграде, одржива архитекmура

Abstract - This paper examines the concept of biomimicry, analysing its principles and possibilities of its application, both in architecture and interior design. An analysis of biomimicry's development through history and biomimetic materials was carried out. Beside good"examples of the application of biomimicry, this paper also presents some examples that are mistakenly considered biomimicry, with a clear explanation of why those are not. At the end, some of the researched and leared biomimetic principles were implemented in the interior and in the exterior of the „Elektrolux" building, located in Novi Sad.

Keywords: Biomimicry, biomimetic, biomimetic materials, business buildings, sustainable architecture

\section{1. УвОД}

„Људски гениј може створити разне изуме, долазећи помоћу различитих инструмената до једног циља, али он никада неће моћи надмашити природу по лепоти, економичности и непосредности, јер у њеном стварању ништа не недостаје нити се ишта расипа“" [1].

Предмет овог истраживања јесте биомимикрија односно биомиметика и на које све начине биомиметички принципи могу имати утицај приликом дизајнирања ентеријера.

Биомимикрија представља адаптивни начин решавања проблема живљења и креирања, опонашањем природних појава и процеса.

\section{НАПОМЕНА:}

Овај рад проистекао је из мастер рада чији је ментор била доц. др Ивана Мишкељин.
Посматрајући природу многи научници и истраживачи су покушавали да разумеју како она функционише. Захваљујући све бољем познавању света који нас окружује, границе човекових открића постају из дана у дан све шире.

"Сваки природни систем обавља одређене функције преузимање угљеника, кружење азота или воде, стабилизовање земље - и све те хранљиве материје које ce крећу кроз систем могу бити квантификоване. Замислите шуму пуну дрвећа, а затим посеците њих пет и саградите зграду на њиховом месту: сада се те функције нужно не изводе. Наш циљ је да разумемо метрике иза свега, као што је рефлексија светлости бивших дрвећа и стопа филтрације воде, и применимо те исте стандарде на објекат тако да он учествује у екосистему на исти начин на који су стабла учествовала. Не ради се о томе да се нема "никакав утицај", већ исти утицај - исти стандард као матерњи систем" [2].

\section{2. БИОМИМИКРИЈА У ПОЉУ АРХИТЕКТУРЕ}

Иако су истраживачи и стручњаци расправљали о различитим облицима биомимикрије или био-инспирисаног дизајна у пољу одрживе архитектуре, практична примена биомимикрије као методе архитектонског дизајна почеком XXI века остаје у великој мери нереализована, што показује мали број изграђених студија случаја. Битно је разумети следеће, да би се дизајн сматрао биомимикријским, није довољна само имитација облика из природе, већ природа мора инспирисати и начин на који се пројектује и материјале који се користе у градњи.

\section{1. Биомеметички материјали}

Посматрајући животиње, биљке и микробе развијени су и биомиметички материјали који се могу дефинисати као материјали који као инспирацију користе природу.

Каталог ових материјала се шири свакодневно, а такође и њихова примена у решавању дизајна грађевинских објеката:

- еко-пријатељски бетон

- фотонапонско ,лишће“

- „Лотусан“ фасадне боје

Примена биомиметичких материјала и биомимикријских принципа у пројектовању зграда доводи до настанка еколошко одрживих објеката који бар једну од својих функција обављају на исти начин као што то неки организми раде у природи. 


\section{3. БИОМИМИКРИЈА У ДИЗАЈНУ ЕНТЕРИЈЕРА}

Дизајн ентеријера најчешће користи биологију као библиотеку облика или украса (Art Nouveau, Jugendstil и слично), али имитирати или бити инспирисан изгледом природних облика, текстурама и бојама само по себи не представља биомимиркију мора садржати неки биолошки принцип у себи.

Оквир за разумевање различитих облика биомимикрије је развијен и користи се приликом одређивања примене биомимикрије у дизајну ентеријера. Овај оквир дефинише различите нивое и приступе, а такође покушава разјаснити потенцијал биомимикрије као алата за решавање проблема који се могу јављати приликом дизајнирања ентеријера.

Дефинисањем врста биомимикрије која се развила, овај оквир може омогућити дизајнерима и архитектима који желе да користе биомимикрију као методологију за унапређење изграђене средине да одаберу најбољи приступ.

Приступи биомимикрији као процесу дизајнирања обично спадају у две категорије, приказане на Слици 1 и описани у [3] :

- приступ заснован на проблему

- приступ заснован на решењу

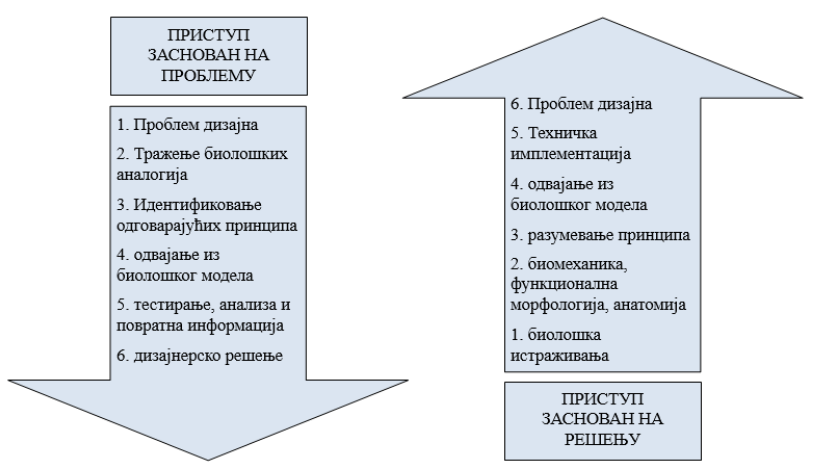

Слика 1: Два приступа биомимикрији

\section{1. Биомимикрија у дизајну намештаја}

\subsection{1 Употреба природних облика}

Као што је већ било речи, природни облици структура у ентеријеру сами по себи не представљају биомимикрију, осим када поред тога што имитирају природни облик, немају још неку фунцкију, као на пример:

- Стварање максималне чврстоће минималном употребом материјала

- Преношење вишесмерних сила кроз закривљене структуре

- Деловање утицаја и напрезања као основа за ефикасност структуралног облика

\subsection{2 Употреба оптималних природних облика}

У даљем тексту дати приказана је сажета анализа најоптималнијих облика, преузетих из природе који имплементирани у дизајн енетеријера и намештаја доводе до минимизације улазног материјала и максимизације чврстоће.

- Решеткасти структурни облици - Скуп груписаних отвора који покривају површину, формирајући облик велике чврстоће, мале тежине, отпоран на силе затезања и притиска. Задржавајући флексибиност, естетику и стабилност. Пример: унутрашњост кости и унутрашња грађа биљака.

- Укрштени и паралелно повезани структурни облици - Ови облици омогућавају минимална улагања материјала, формирајући структуре малих тежина и велике чврстоће. Пример: људске кости и структура птичијег гнезда.

- Закривљени структурни облици - Употребом закривљених облика добијају се чврсте структуре мале тежине, које умањују сила затезања, боље примају и подносе оптерећења уз минимално улагање напора и материјала. Осим тога, код оваквих структура пукотине се лакше савладавају и не утичу превише на функционисање саме структуре. Пример: кости унутар људског тела.

- Структурни облици вена или набора - Коришћењем оваквих облика приликом изградње таваница, повећава се носивост уз мало улагање материјала и без повећања тежине саме таванице. Пример: вене у крилима инсеката, вене и набори на поједином лишћу. - Интеративни облици - Облик који се понавља ради добијања одређене структуре, углавном је мале тежине и понавља се тако што је свака следећа интерација мањих димензија. Пример: гранање дрвећа.

- Облици засновани на златном пресеку

\section{4. ПРИМЕНА ПРИНЦИПА БИОМИМИКРИЈЕ У ЕНТЕРИЈЕРУ ПОСЛОВНОГ ОБЈЕКТА}

Након свих анализа, истраживања, сакупљања података, селекције проблема, последњи корак је креирање пројектног решења, које ће дати адекватан одговор на пројектни задатак, који захтева ревитализацију и ново дизајнерско решење задатог објекта, уз примену биомимикријских принципа, поштујући основне архитектонске услове.

\section{1. Анализа локације}

Изабрани објекат за ревитализацију и тема овог рада представља зграда „Elektrolux“-а у Новом Саду, која је смештена у улици Ласла Гала, тачна локација означена је на Слици 2.

За објекте пословног карактера, као што је и овај, битно постављање и оријентација, како би се омогућио лакши и бржи приступ објекту и садржајима које нуди.

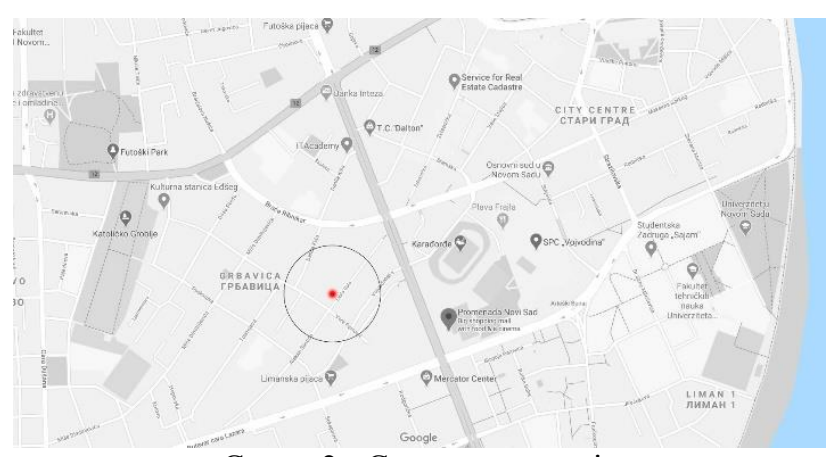

Слика 2 : Снимак локације 


\section{2. Просторни концепт и конструкција}

На стварање концепта ревитализације објекта утицали су принципи одрживог развоја и постојећа архитектура. Основни циљ био је задржавање форме постојећег објекта уз минималне промене диктиране од стране нове организације и намене простора а такође и промене дотрајале конструкције.

Контрукцију овог објекта чине скелетни систем који се састоји од стубова и греда. Како би цела структура била лакша у унутрашњости објекта имплементирани су модуларни дрвени стубови, који су испресецани па самим тим не делују масивно и не нарушавају ентеријер већ чине његов битан, препознатљив елемент. У деловима галерије стубови су видљиви целом висином и ту се најбоље може сагледати њихов облик, који је добијен принципом биомимикрије и који опонаша структуру костију, својим променљивим попречним пресеком, који се шири у оном делу у ком су оптерећења највећа. Лаке таванице постављене су на дрвене гредице које се простиру целом површином плафона, стапајући се са дрвеним стубовима и у неким деловима ослањајући се на њих, што доводи до елиминисања тешких греда у ентеијеру, с обзиром на то да ове греде примају и преносе оптерећење целом површином.

Осим таванице и стубова, била је потребна и реконструкција дотрајале кровне конструкције. Ова реконструкција допустила је стварање стаклених отвора у новој конструкцији који ће пропуштати светлост у ентеријер, тамо где је то најпотребније

\section{3. Функционална организација простора}

Постојећи објекат који представља предмет ревитализације био је приземни објекат на који је због могућности смештања већег броја просторија подигнут један спрат, те је сада спратности П+1. Позиција улаза је задржана, с тим што је додат и тзв. помоћни улаз. Функционална организација је у потпуности промењена и приказана је на Слици 3:
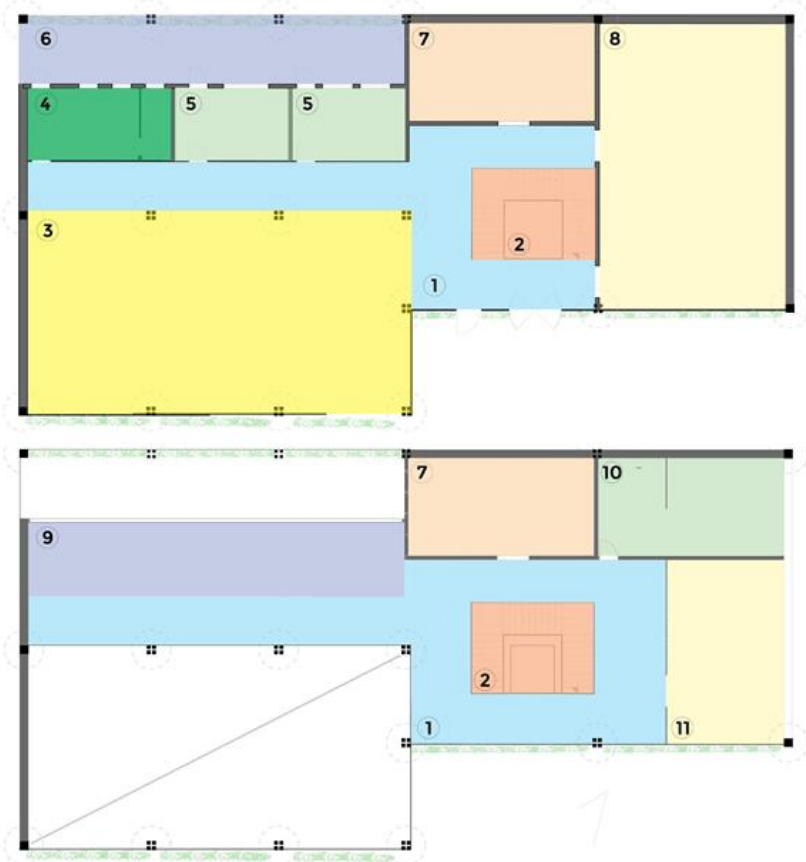

Слика 3 : Функциионална организацฺија
ЛЕГЕНДА:

1. Хоризонтална комуникација

2. Вертикална комуникација

3. Простор за одмор

4. Кухиња

5. Администрација

6. Отворени простор за одмор

7. Тоалети

8. Конференцијска сала

9. Open space

10. Канцеларија

11. Сала за састанке

\section{4. Примењени принципи биомимикрије}

Приликом ревитализације објекта имплемнтирано је неколико принципа биомимикрије и то:

1. Оптимални природни облици коришћени у ентеријеру

Ово је један од најзаступљенијих принципа који се може видети у ентеријеру новопројектованог пословног простора.

\section{- Закривљени структурни облиции}

Већи део намештаја у пројекту чине закривљени структурни облици, код којих се умањују силе затезања, боље примају и подносе оптерећења уз минимално улагање напора и материјала. Намештај оваквог облика лашке савладава могуће пукотине које и уколико се десе не утичу превише на носивост и функционисање саме структуре. Најдоминантнији намештај овог зипа приказан је на Слици 4.

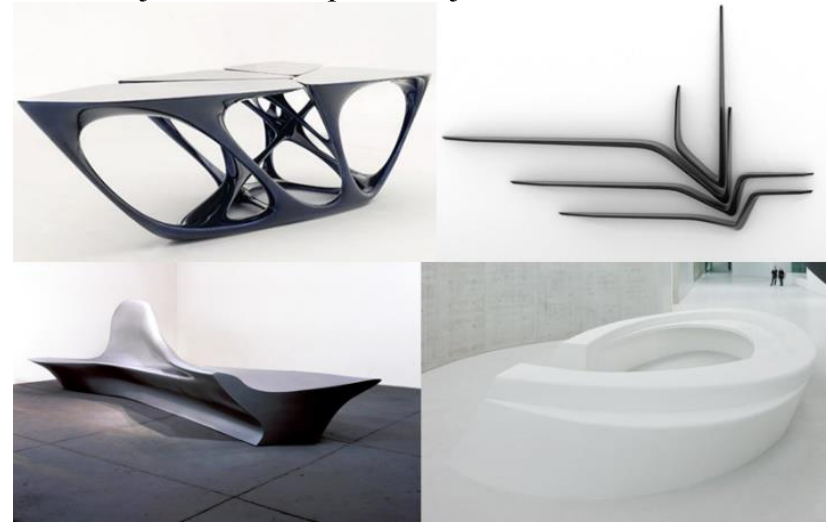

Слика 4 : Закривљени намештај

\section{- Решеткасти структурни облиции}

Све решеткасте структуре које се појављују на објекту имају хексагонални облик, због свих његових предности, односно због заузимања мале површине, минималне употребе материјала и непостојања шупљина односно неискоришћеног простора у структури. Таква је на пример новопројектована кровна конструкција, на којој се појављују стаклени отвори, који изискују већу носивост. Осим тога, хексагонална решеткаста структура појављује се и на фасади и њу чине челични носачи, малих димензија које носе соларни бршљан. У овом случају се релативно танким профилима добила чврста мрежа која конструктивно задовољава све карактеристике а да притом не урушава ентеријер, нити доминира у односу на само лишће бршљана 


\section{- Структурни облиции вена}

Коришћењем оваквих облика приликом изградње таваница, довело је до повећања носивост уз мало улагање материјала и без повећања тежине саме таванице. Осим тога избегнута је употреба масивних греда које би у потпуности промениле сам изглед ентеријера и смаљиле би ефекат „лакоће“ за којим се тежило током целог процеса пројектовања и ревитализације. Дрвене гредице постављене су у правцу у коме се јавља савијање и знатно су дошринеле естетици самог ентеријера, уводећи динамику у сам простор.

\section{- Паралелно повезани структурни облици}

Примена овог принципа може се видети на дизајну стубова ревитализованог овјекта. Међусобно повезани, паралелни, дрвени елементи стварају чврсту структуру, мале тежине и минималних улагања материјала. Ови стубови показују варијације у свом пресеку, целом висином, одлагајући материјал и ширећи се тамо где је најпотребније.

\section{2. Фотонапонско ,лишће“}

Још један, веома доминантан елемент у дизајну који умногоме доприноси одрживом развоју али и естетици екстеријера а такође и ентеријера јесте раније споменути систем фотонапонског лишћа „Solar Ivy“ - Соларни бршљан. Осим што прикупља енергију сунца и ветра ради напајања зграде, у овом случају одлука за ово решење донета је првенствено због потребе обезбеђивања хлада у ентеријеру објекта, због отварања јужне фасаде целом дужином. Тиме долази до смањења трошкова климатизације а објекат се уједно штити од удара ветрова, што зими смањује и трошкове грејања. Изгледом потпуно опонашајући природни изглед и боју листа бршљана, корисницима ентеријера пружа одличне визуре које позитивно делују на продуктивност и пословни учинак.

\section{3. Облога пода „Ентропија“}

Као облога пода, преко ливеног бетона, постављене су „тепих“ плочице, хексагоналног облика. Ове плочице различитих су боја, без строгог низа и распореда, што доприноси лакшој усклађености и замени једне плочице, уколико је потребно. Једноставно се постављају што резултира смањењем отпада па самим тим и трошкова. Овај „организовани хаос“ на поду даје посебну динамику целокупном простору, а пастелне боје чине да под изгледа као шумски покривач сачињен од лишћа различитих боја.

\section{4. Фасадне боје „Лотусан“"}

Главна карактеристика ове боје јесте што се она сама чисти, услед кише, што знатно смањује трошкове одржавања. Површина ове боје има облик густо набијених избочина, чије је својство спречавање ширења капи воде, које "клижу" са површине, скидајући истовремено прљавштину. Принцип имитира принцип чишћења листа лотоса.

\section{5. ЗАКЉУЧАК}

Проблеми са околином у којој живимо су стварни. Како бисмо успевали даље да задовољимо своје егзистенцијалне потребе и како бисмо успели да омогућимо будућим генерацијама да несметано задовоље своје потребе, морамо озбиљно да се позабавимо проблемом нашег окружења.

Свака област људског деловања може да се прилагоди принципима одрживог развоја а тако и архитектура па и дизајн ентеријера. Један начин постизања одрживости у архитектури и ентеријеру јесте биомимикрија, која је детаљно била истраживана у овом раду.

Можемо рећи да употреба биомимикрије као методологија решавања проблема може помоћи у стварању нових одрживих стандарда за унутрашње просторе, зграде, заједнице и градове широм света. За архитекте и дизајнере биомимикрија отвара потпуно нови свет иновативних идеја за трансформацију ентеријера и требало би је више применити у будућности, с обзиром на то да се биомимикрија за сада у унутрашњем окружењу и даље налази у почетној фази развоја. Упркос све већем броју био-инспирисаних матријала и производа који проширују могућности пројектовања пријатељског оркужења и који су доступни дизајнерима, пројекти који је укључују на већем нивоу су ретки.

Циљ овог рада и пројекта био је, осим стварања пријатног радног окружења, које утиче на продуктивност, расположење и смањење стреса његових корисника, скретање пажње на природу и широк спектар решења које она нуди јер је утврђено да укључивање природе у дизајнирање помаже у сузбијању еколошке проблематике. Дизајнери ентеријера морају прећи њене формалистичке карактеристике и подстаћи људе да развију дубље и одговорније разумевање исте.

Након што је установљено да биомимикрија није само и нужно изглед, овим пројектом извршена је интеграција архитектуре у природу и интеграција природе у архитектуру, на више нивоа, као што би увек требало да буде како би се успоставио и одржавао савршени баланс.

\section{6. ЛИТЕРАТУРА}

[1] Codex Leicester - бележница рукописа Леонарда да Винчија 1506-1510

[2] Bioinspiration in Business and Management: Innovating for Sustainability - Taryn Mead 2017

[3] Biomimicry: Innovation Inspired by Nature - Janine Benyus 1997

\section{Кратка биографија:}

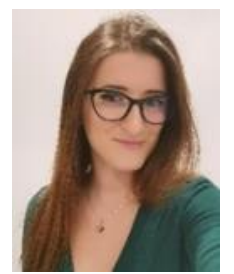

Кристина Оморан рођена је у Вршцу 1994. године. Основне студије на Факултету техничких наука из области „Архитектура и урбанизам“ завршила је 2018.год када је уписала Мастер студије усмерење „Дизајн ентеријера“. Мастер рад одбранила је 2020.год. 